\title{
Rhodotorula rosulata sp. nov., Rhodotorula silvestris sp. nov. and Rhodotorula straminea sp. nov., novel myo-inositol-assimilating yeast species in the Microbotryomycetes
}

Correspondence Wladyslav I. Golubev wig@ibpm.pushchino.ru

\author{
Wladyslav I. Golubev ${ }^{1}$ and Gloria Scorzetti ${ }^{2}$ \\ ${ }^{1}$ Russia Collection of Microorganisms (VKM), Institute for Biochemistry and Physiology of \\ Microorganisms, Russian Academy of Sciences, Pushchino, 142290, Russia \\ ${ }^{2}$ Rosenstiel School of Marine and Atmospheric Science, University of Miami, Miami, FL, USA
}

A distinguishing feature of the majority of the tremellomycetous yeasts is their ability to utilize a cyclitol, myoinositol, as sole source of carbon and energy. This characteristic, which, as a rule, is not shared by ascomycetous yeasts and by basidiomycetous yeasts of other classes, represents a fundamental key in yeast identification. Specifically, inositol assimilation is a criterion used to distinguish between anamorphic yeasts of the genera Cryptococcus Vuillemin and Rhodotorula Harrison (Kurtzman \& Fell, 1998; Barnett et al., 2000). With a few exceptions, species of the genus Cryptococcus (subphylum Agaricomycotina) utilize both myo-inositol and D-glucuronate, the first intermediate of inositol catabolism, whereas species belonging to the genus Rhodotorula typically do not assimilate myo-inositol, and D-glucuronate assimilation is variable within this genus. Eukaryotes metabolize myoinositol via the D-glucuronate-L-gulonate pathway (Golubev, 1989), i.e. the sole step only, the oxidation of myo-inositol to D-glucuronate, is absent in D-glucuronatepositive but myo-inositol-negative Rhodotorula species.

The advent of nucleotide sequence analysis demonstrated the polyphyletic nature of the genus Rhodotorula, which today is united by the absence of ballistoconidia (Fell et al.,

Abbreviation: ITS, internal transcribed spacer.

The GenBank/EMBL/DDBJ accession numbers for the LSU rDNA gene D1/D2 domain sequences determined in this study are EU872490, GQ121044 and EU872489. Accession numbers for the ITS region sequences are EU872492, GQ121045 and EU872491.

Phylogenetic trees based on sequence analysis of the D1/D2 domains of the LSU rDNA gene and the ITS regions are available with the online version of this paper.
2000; Scorzetti et al., 2002). Species of this genus are found in the subphyla Ustilaginomycotina and Pucciniomycotina (Aime et al., 2006). The genus Rhodotorula sensu stricto, with the type species Rhodotorula glutinis (Fresenius) Harrison, is within the Sporidiobolales (Microbotryomycetes). Those species [Rhodotorula araucariae Grinbergs et Yarrow, $R$. colostri (Castelli) Lodder, $R$. dairenensis (Hasegawa et Banno) Fell et al., R. glutinis, R. graminis di Menna, $R$. mucilaginosa (Jörgensen) Harrison and $R$. pacifica Nagahama et Hamamoto] do not utilize either myo-inositol or D-glucuronate. In contrast, the majority of the species (mainly former species of the genus Candida) that reside elsewhere in the Pucciniomycotina are capable of utilizing D-glucuronate but fail to assimilate myo-inositol. Rare exceptions are members of the Ustilaginomycotina [Rhodotorula phylloplana (Shivas et Rodrigues de Miranda) Rodrigues de Miranda et Weijman], some strains of Rhodotorula bacarum (Buhagiar) Rodrigues de Miranda et Weijman, and among the Microbotryomycetes [Rhodotorula yarrowii (Fonseca et van Uden) Boekhout et al.].

During a survey of yeasts from pine and spruce dead needle litters we found several isolates that were positive for both myo-inositol and D-glucuronate assimilation. A rDNA gene sequence analysis and a comparison of their phenotypic properties revealed that the isolates constitute novel anamorphic species in the Microbotryomycetes, for which the names Rhodotorula rosulata sp. nov., Rhodotorula silvestris sp. nov. and Rhodotorula straminea sp. nov. are proposed.

The strains (isolation numbers: Pa-78, Pa-84, Pa-85, Ps-88, Ps-93, Ps-103, Ps-128 and Ps-130) were isolated from dead 
needles collected underneath Picea abies (L.) Karst. and Pinus sylvestris L. trees in a mixed forest (Moscow region, Russia) in October 2006 and May 2007. Serial dilutions of needle washings were plated onto spruce or pine needle agar and incubated at room temperature for 1-2 weeks. Needle infusion agar was prepared in the following way: $200 \mathrm{~g}$ dead spruce or pine needles were put into flasks with 11 water, and boiled for $10 \mathrm{~min}$. The liquid was filtered through gauze and water was added to the filtrate to make up $1 \mathrm{l}$. After adding $20 \mathrm{~g}$ agar, the medium was autoclaved for $15 \mathrm{~min}$ at 15 p.s.i. (103.5 $\mathrm{kPa}$ ) overpressure. When the temperature cooled down to $50-60{ }^{\circ} \mathrm{C}$, streptomycin (500 mg) was added, and the medium was poured into sterile Petri dishes. The total culturable yeast populations of spruce and pine dead needles were approximately

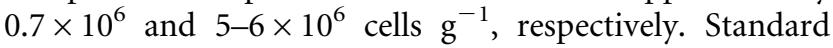
methods in yeast taxonomy were employed for morphological and physiological characterization (Yarrow, 1998). The procedure for determining mycocin sensitivity patterns was described previously (Golubev et al., 2006).

DNA was directly amplified by adding a light cell suspension in water to a PCR mixture, which comprised $5 \mu \mathrm{l}$ buffer (containing $15 \mathrm{mM} \mathrm{MgCl}$ ), 10 pmol each primer, $1.5 \mu \mathrm{l}$ dNTPs $(10 \mathrm{mM})$ and 1.5 units DNAzyme polymerase (New England Biolabs). Sterile water was added to bring the mixture to the final volume $(50 \mu \mathrm{l})$. Sequences for the primer pairs [forward F63 and reverse LR3 for the D1/D2 domains of the LSU rDNA gene and forward ITS1 and reverse ITS4 for the internal transcribed spacers (ITS) 1 and 2] were previously reported (Fell et al., 2000).

The PCR program consisted of one cycle of denaturation at $95{ }^{\circ} \mathrm{C}$ for five minutes followed by 30 cycles of $30 \mathrm{~s}$ denaturation at $95{ }^{\circ} \mathrm{C}, 30 \mathrm{~s}$ annealing at $50{ }^{\circ} \mathrm{C}$ and one minute extension at $70{ }^{\circ} \mathrm{C}$. The final extension at $72{ }^{\circ} \mathrm{C}$ was for eight minutes. The program was run in a PTC-200 Thermocycler (MJ Research). Samples were checked by electrophoresis on a $2 \%$ agarose gel and purified (QIAquick PCR purification kit, Qiagen). Sequencing was performed on an ABI 3730 sequencer (Applied Biosystems) with the same primers used in the amplification. The sequences obtained were analysed with Seqman 5.51 (DNASTAR for MacOSx), visually corrected, analysed through GenBank BLAST and aligned in MEGALIGN (DNASTAR for MacOSx) with related sequences available in GenBank. Sequences obtained were deposited into the GenBank database. Phylogenetic analysis employed PAUP 4.0b 10 with likelihood analysis (heuristic search, stepwise addition). Bootstrap values were calculated on 1000 replicates for trees based on single regions and on 100 replicates for the combined tree.

The strains studied formed colourless or greyish-cream colonies. They were characterized by elongate, fusiform, often curved cells and could produce rudimentary pseudohyphae but not septate hyphae. Teliospores or ballistoconidia were not observed. These isolates were negative in the starch-like compounds formation test, but strains Ps-93 and Ps-128 gave a greenish colour. No mating reactions or sexual structures were observed either in single or mixed-strain cultures (corn meal agar, $20{ }^{\circ} \mathrm{C}$, two weeks). Positive urease and diazonium blue $\mathrm{B}$ reactions showed their basidiomycetous affinity. In addition, the strains assimilated myo-inositol and D-glucuronate, and alcoholic fermentation was absent. The isolates differed in their ability to assimilate D-galactose, raffinose, melibiose, cellobiose, arbutin, salicin, L-sorbose, L-rhamnose, creatine and creatinine. Positive myo-inositol assimilation would suggest that the new isolates belong to the genera Cryptococcus or Rhodotorula, a hypothesis supported by their physiological profiles (Barnett et al., 2000) that showed similarity with Cryptococcus albidus (Saito) Skinner and $R$. yarrowii (described originally as Cryptococcus yarrowii Fonseca et van Uden).

None of these isolates was sensitive to mycocins produced by representatives of the genera Cryptococcus, Cystofilobasidium Oberwinkler et Bandoni, Filobasidium Olive, Rhodotorula and Sporidiobolus Nyland, while it has been known that mycocins are active against species phylogenetically related to mycocinogenic strains (Golubev, 2006).

Sequence analysis of the D1/D2 domains of the 26S rDNA gene and the ITS regions demonstrated that our isolates are members of the Pucciniomycotina and cluster within the Microbotryomycetes (Aime et al., 2006).

Isolates $\mathrm{Pa}-78, \mathrm{~Pa}-84, \mathrm{~Pa}-85, \mathrm{Ps}-88$ and Ps-103 share identical sequences in both regions. They are closely related to $R$. yarrowii, with 4 base pairs difference in the D1/D2 region and 23 in the ITS region, and to isolate Ps-130, which differs from $R$. yarrowii by 6 base pairs in the D1/D2 region (Supplementary Fig S1, available in IJSEM Online) and by 41 in the ITS region (Supplementary Fig S2). Mismatches between isolate Ps-130 and isolates $\mathrm{Pa}-78, \mathrm{~Pa}-84, \mathrm{~Pa}-85$, Ps83 and Ps-103 amount to 9 in the D1/D2 region and to 33 in the ITS region. The above-mentioned isolates and $R$. yarrowii group together in a cluster with high bootstrap values in either regions (99\% in D1/D2 and $100 \%$ in ITS).

The two remaining isolates studied, Ps-93 and Ps-128, also have identical sequences in both regions. The closest species in the D1/D2 tree (Supplementary Fig S1) is Rhodotorula psychrophenolica with 9 mismatches, but low bootstrap support (less than 50\%). The ITS data (Supplementary Fig S2) apparently linked these strains with Kriegeria eriophori Bresadola (anamorph - Zymoxenogloea eriophori McLaughlin et Doublés) in a placement due to long branch attraction. A larger cluster, comprising also Rhodotorula glacialis Margesin et Sampaio, $R$. himalayensis Shivaji et al., R. psychrophenolica and $R$. psychrophila Margesin et Sampaio, reported instead $83 \%$ bootstrap support. All our isolates showed a higher number of nucleotide differences from other described species in the cluster than the ones existent between the same recognized species. For example, based on our alignment analysis, $R$. himalayensis and $R$. glacialis differ in the ITS regions by 3 base pairs and R. glacialis and R. psychrophila differ at 6 base positions. In the D1/D2 regions $R$. psychrophila and $R$. 
glacialis differ at 5 positions, whereas $R$. glacialis and $R$. himalayensis differ by 8 base pairs.

A dataset comprised of the combined sequences (ITS regions and D1/D2 domains of the $26 \mathrm{~S} \mathrm{rDNA}$ gene) is shown in Fig. 1, thus confirming the relationships and divergences illustrated in the two previous trees (Supplementary Figs S1 and S2). In the tree reconstructed from the three groups, our isolates were also related to $K$. eriophori or $R$. yarrowii but could be clearly distinguished from them and from each other.

Therefore, the results of the phylogenetic analyses and the above-mentioned phenotypic distinctions led us to conclude that our isolates from needle litter represent three novel species for which the names Rhodotorula rosulata sp. nov. (Ps-93 ${ }^{\mathrm{T}}$ and Ps-128), Rhodotorula silvestris sp. nov. (Pa-78 ${ }^{\mathrm{T}}, \mathrm{Pa}-84, \mathrm{~Pa}-85, \mathrm{Ps}-88$ and Ps-103) and Rhodotorula straminea sp. nov. $\left(\mathrm{Ps}-130^{\mathrm{T}}\right)$ are proposed.

The three novel species demonstrate significant physiological similarities with related species assigned to the genus Rhodotorula. All these species (with the exception of $R$. himalayensis) are able to utilize D-glucuronate, sucrose, Dmannitol, D-gluconate, nitrate and ethylamine but the utilization of lactose, D-arabinose, D-ribose and erythritol is negative. Differentiating characteristics are based on maximum growth temperatures and utilization of carbon and nitrogen compounds such as myo-inositol, raffinose, melibiose, cellobiose, L-sorbose, L-rhamnose, D-galactose, ethanol, DL-lactate, citrate and creatinine (Table 1). Among the myo-inositol-positive species, $R$. rosulata sp. nov. can be differentiated by positive reactions on cellobiose, L-rhamnose and creatinine and negative responses to raffinose, melibiose and L-sorbose. $R$. straminea sp. nov. can assimilate raffinose and L-sorbose but not melibiose, cellobiose, Lrhamnose and creatinine. R. silvestris sp. nov. and R. yarrowii are very similar in their physiological profiles, differing only in the rate of utilization of some carbon sources (Table 1). The most clear-cut distinction between these two species is related to $\beta$-glucosidase activity that is absent or very low in $R$. yarrowii and results in weak or no growth for this species on cellobiose, arbutin and salicin. The opposite situation is observed for $R$. silvestris sp. nov. The two species differ phylogenetically by four nucleotides in the D1/D2 domains and 23 in the ITS regions.

It is necessary to emphasize that the assignment of novel species to the genus Rhodotorula must be considered provisional as this polyphyletic genus is very heterogeneous at present (Aime et al., 2006).

\section{Latin diagnosis of Rhodotorula rosulata Golubev et Scorzetti Sp. nov.}

In aqua D-glucosum et peptonum et extractum fermenti continente, post dies 3 cellulae elongate, fusiformes, parum curvatae, guttatae, $(1.7-4.3 \times 8.5-17.9 \mu \mathrm{m})$, singulae, binae vel in rosulatae; gemmatione polari reproducentes, gemmae in fulcris quoque formantur. Post unum mensem, pellicula crassa et sedimentum formantur. In agaro morphologico (Difco) post unum mensem cultura in striis griseocremea, glabra vel rugosa, opaca, butyrosa, margo integra. Ballistoconidia nulla. In agaro farina Zea maydis confecto post dies 10 pseudohyphae primitivae formantur. Status sexualis non apparet. Non fermentat. DGlucosum, D-glucosaminum (exigue), N-acetylglucosaminum, D-xylosum (exigue), L-rhamnosum, sucrosum, maltosum

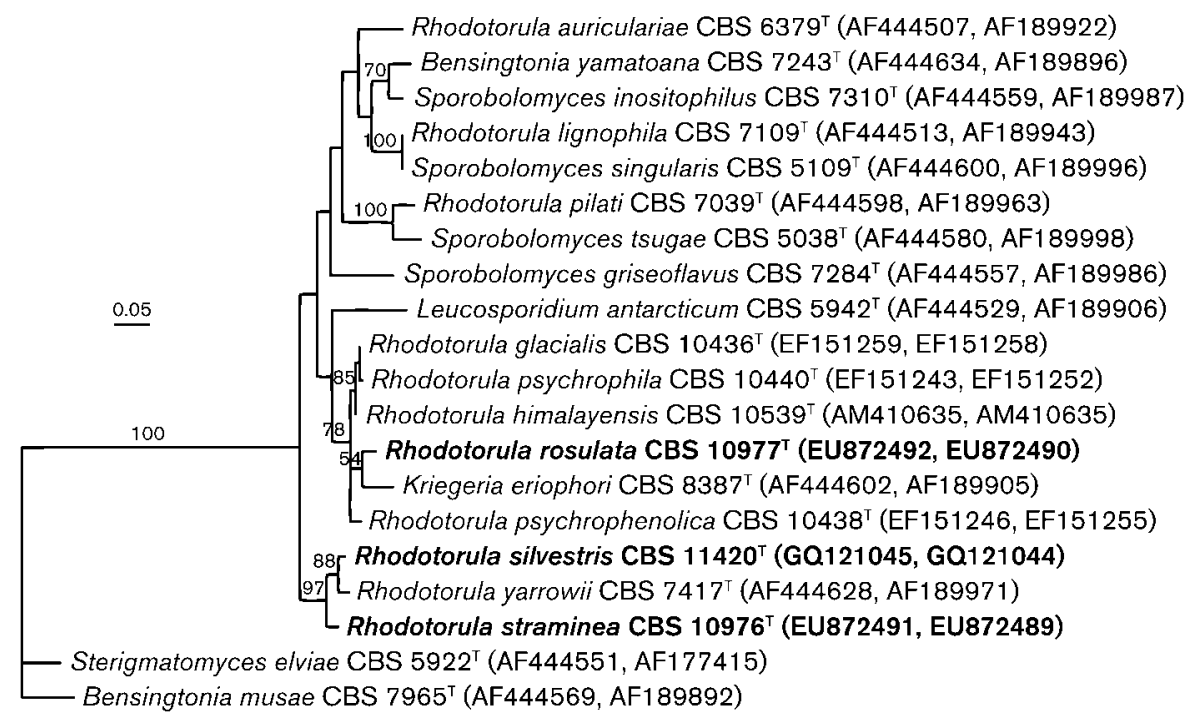

Fig. 1. Phylogenetic tree based on the ITS regions and the D1/D2 domains of the LSU rDNA gene (maximum-likelihood heuristic search, stepwise addition). Bootstrap values calculated were based on 100 replicates and reported on the branches when greater than $50 \%$. GenBank accession numbers are indicated in parentheses. Sequences determined by the authors are in boldface. Bar, 0.05 substitutions per site. 
Table 1. Physiological characteristics differentiating the three novel species from the nearest glucuronate-positive phylogenetic neighbours

Species: 1, R. glacialis; 2, R. psychrophila; 3, R. psychrophenolica; 4, R. rosulata sp. nov.; 5, $R$. straminea sp. nov.; 6, $R$. silvestris sp. nov.; 7, $R$. yarrowii. Data from this study, Fell \& Statzell-Tallman (1998), Margesin et al. (2007) and Shivaji et al. (2008). +, Positive; d, delayed response; $\mathrm{w}$, weakly positive; -, negative response.

\begin{tabular}{|lccccccc|}
\hline Characteristics & $\mathbf{1}$ & $\mathbf{2}$ & $\mathbf{3}$ & $\mathbf{4}$ & $\mathbf{5}$ & $\mathbf{6}$ & $\mathbf{7}$ \\
\hline Carbon sources & & & & & & & \\
Raffinose & + & + & + & - & + & + & + \\
Melibiose & - / & - & - & - & - & $\mathrm{d}$ & + \\
D-Galactose & - & - & - & - & $\mathrm{w}$ & $\mathrm{W}$ & $\mathrm{W}$ \\
Cellobiose & - & - & - & $\mathrm{d}$ & - & $\mathrm{d}$ & $-/ \mathrm{W}$ \\
L-Sorbose & - & - & - & - & $\mathrm{w}$ & $\mathrm{d}$ & $\mathrm{W}$ \\
L-Rhamnose & - / & - & + & + & - & - & - \\
Ethanol & - & - & - & + & + & $\mathrm{d}$ & + \\
myo-Inositol & - & - & - & + & + & + & + \\
DL-Lactate & - & - & - & $\mathrm{d}$ & $\mathrm{d}$ & $\mathrm{d}$ & $\mathrm{d}$ \\
Citrate & - & - & - & $\mathrm{d}$ & $\mathrm{d}$ & $\mathrm{d}$ & $\mathrm{d}$ \\
Nitrogen source & & & & & & & \\
Creatinine & + & + & + & + & - & - & - \\
Growth at: & & & & & & & \\
$20{ }^{\circ} \mathrm{C}$ & + & - & + & + & + & + & + \\
$25{ }^{\circ} \mathrm{C}$ & - & - & - & + & + & + & + \\
\hline
\end{tabular}

(lente), trehalosum (exigue), cellobiosum (lente), melezitosum, arbutinum (lente), salicinum (lente), amylum (exigue), ethanolum, glycerolum (exigue), ribitolum (exigue), D-glucitolum (lente), D-mannitolum, myo-inositolum, D-glucuronatum, Dgluconatum, 2-keto-D-gluconatum, 5-keto-D-gluconatum, Dglucaratum, acidum quinicum, succinatum, citratum (lente) et DL-lactatum (lente) assimilantur neque inulinum, D-galactosum, raffinosum, methyl $\alpha$-D-glucosidum, melibiosum, lactosum, L-sorbosum, D-ribosum, L-arabinosum, D-arabinosum, erythritolum, xylitolum, L-arabitolum et galactitolum. Kalium nitricum, kalium nitrosum, ethylaminum, D-glucosaminum, cadaverinum, L-tryptophanum, L-lysinum (lente), creatinum et creatininum assimilantur. Vitamina externa at crescentiam necesseria sunt. Reactiones Diazonium blue B et ureasii positivae. Materia amyloidea iodophila non formatur. Crescit in $25{ }^{\circ} \mathrm{C}$, non crescit in $30{ }^{\circ} \mathrm{C}$. Typus Ps $-93^{\mathrm{T}}$ isolates ex foliis acicularibus Pinus sylvestris L. delapsis (Rossia), conservatur in collectione micro-organismorum (=VKM Y-2962 ${ }^{\mathrm{T}}$ ) Acad. Sci. Rossicum (Pushczino, Rossia) et in collectione zymotica (=CBS $10977^{\mathrm{T}}$ ) Centraalbureau voor Schimmelcultures (Utrecht, Hollandia).

\section{Description of Rhodotorula rosulata Golubev et Scorzetti sp. nov.}

Rhodotorula rosulata (ro.su.la'ta. N.L. fem. adj. rosulata in the form of a rosette, rosetted, referring to cell groupings).

After 3 days in D-glucose/yeast extract/peptone broth, cells are elongate, fusiform, sometimes slightly curved, width/length ratio $2.5-8.0$ (mean 4.7), 1.7-4.3 ×8.5$17.9 \mu \mathrm{m}$ (mean $3.0 \times 12.8 \mu \mathrm{m})$, single, in pairs or in rosette groups, and contain oil droplets (Fig. 2). Reproduces by polar budding; buds can develop on stalks. After 1 month, a thick pellicle and a sediment are formed. Streak culture on yeast morphology agar (Difco) is greyish-cream, smooth to wrinkled, dull and butyrous with an entire margin. No ballistoconidia are observed. After 10 days in slide cultures on corn meal agar a primitive pseudomycelium is produced. No sexual state is observed. Fermentation is absent. The following carbon compounds are assimilated: D-glucose, D-glucosamine (weak), $\mathrm{N}$ acetylglucosamine, D-xylose (weak), L-rhamnose, sucrose, maltose (delayed), trehalose (weak), cellobiose (delayed), melezitose, arbutin (delayed), salicin (delayed), soluble starch (weak), ethanol, glycerol (weak), ribitol (weak), Dglucitol (delayed), D-mannitol, myo-inositol, D-glucuronate, D-gluconate, 2-keto-D-gluconate, 5-keto-D-gluconate, D-glucarate, quinic acid, succinate, citrate (delayed) and DL-lactate (delayed). No growth occurs on inulin, D-galactose, raffinose, methyl $\alpha$-D-glucoside, melibiose, lactose, L-sorbose, D-ribose, L-arabinose, D-arabinose, erythritol, xylitol, L-arabitol and galactitol. Utilization of nitrogen compounds: positive for nitrate, nitrite, ethylamine, D-glucosamine, cadaverine, L-tryptophan, L-lysine (delayed), creatine and creatinine. Reactions to Diazonium blue $\mathrm{B}$ and urease are positive. Starch-like compounds are not produced. Growth in vitamin-free medium is absent. Growth occurs at $25{ }^{\circ} \mathrm{C}$ but not at $30{ }^{\circ} \mathrm{C}$.

The type strain Ps-93 ${ }^{\mathrm{T}}$ (=VKM Y $-2962^{\mathrm{T}}=\mathrm{CBS} 10977^{\mathrm{T}}$ ) was isolated from dead needles of Pinus sylvestris L. in Moscow region (Russia).

\section{Latin diagnosis of Rhodotorula silvestris Scorzetti et Golubev sp. nov.}

In aqua D-glucosum et peptonum et extractum fermenti continente, post dies 3 cellulae elongate, fusiformes, curvatae, guttatae, $(1.7-6.0 \times 5.9-12.8 \mu \mathrm{m})$, singulae vel binae, gemmatione polari reproducentes. Post unum mensem, pellicula crassa et sedimentum formantur. In agaro morphologico (Difco) post unum mensem cultura in striis griseocremea, glabra, nitida, butyrosa, margo integra. Ballistoconidia nulla. In agaro farina Zea maydis confecto post dies 10 pseudohyphae primitivae formantur. Status sexualis non apparet. Non fermentat. D-Glucosum, D-glucosaminum (exigue), N-acetylglucosaminum, melibiosum (lente), D-galactosum (exigue), L-sorbosum (lente), D-xylosum (exigue), sucrosum, maltosum (lente), trehalosum (lente), cellobiosum (lente), melezitosum, raffinosum, arbutinum (lente), salicinum (lente), ethanolum (lente), glycerolum (lente), ribitolum (lente), D-glucitolum, D-mannitolum, myo-inositolum, D-glucuronatum, D-gluconatum, 2-keto-D-gluconatum, 5-keto-D-gluconatum, D-glucaratum, acidum quinicum, succinatum, citratum (lente) et DL-lactatum (lente) assimilantur neque inulinum, methyl $\alpha$ D-glucosidum, amylum, lactosum, D-ribosum, L-arabinosum, D-arabinosum, L-rhamnosum, erythritolum, xylitolum, 


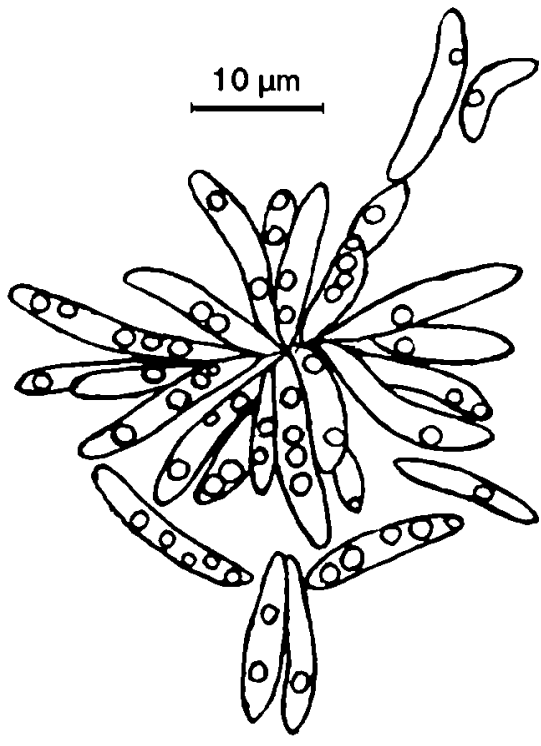

Fig. 2. Rhodotorula rosulata sp. nov. VKM Y $-2962^{\top}$ after 3 days on malt agar at $20^{\circ} \mathrm{C}$. Bar, $10 \mu \mathrm{m}$.

L-arabitolum et galactitolum. Kalium nitricum, kalium nitrosum, ethylaminum (lente), D-glucosaminum, L-lysinum (lente) et cadaverinum (lente) assimilantur, creatinum et creatininum non assimilantur. Vitamina externa at crescentiam necesseria sunt. Reactiones Diazonium blue B et ureasii positivae. Urea finditur. Materia amyloidea iodophila non formatur. Crescit in $25{ }^{\circ} \mathrm{C}$, non crescit in $30{ }^{\circ} \mathrm{C}$. Typus Pa$78^{\mathrm{T}}$ isolates ex foliis acicularibus Picea abies (L.) Karst. delapsis (Rossia), conservatur in collectione micro-organismorum (=VKM Y-2971 ${ }^{\mathrm{T}}$ ) Acad. Sci. Rossicum (Pushczino, Rossia) et in collectione zymotica $\left(=\mathrm{CBS} \quad 11420^{\mathrm{T}}\right)$ Centraalbureau voor Schimmelcultures (Utrecht, Hollandia).

\section{Description of Rhodotorula silvestris Scorzetti et Golubev sp. nov.}

Rhodotorula silvestris (sil.ves'tris. L. fem. adj. silvestris belonging to a forest, referring to the origin of the isolates).

After 3 days in D-glucose/yeast extract/peptone broth, cells are elongate, fusiform, often curved, width/length ratio 1.9-5.3 (mean 3.3), 1.7-6.0 ×5.9-12.8 $\mu \mathrm{m}$ (mean 3.2$10.7 \mu \mathrm{m}$ ), reproducing by polar budding, single or in pairs, and contain oil droplets. After 1 month, a thick pellicle and a sediment are formed. Streak culture on yeast morphology agar (Difco) is greyish-cream, smooth, glistening and butyrous with an entire margin. No ballistoconidia are observed. After 10 days in slide cultures on corn meal agar a primitive pseudomycelium is produced. No sexual state is observed. Fermentation is absent. The following carbon compounds are assimilated: D-glucose, D-glucosamine (weak), $N$-acetylglucosamine, melibiose (delayed), Dgalactose (weak), L-sorbose (delayed), D-xylose (weak), sucrose, maltose (delayed), trehalose (delayed), cellobiose (delayed), melezitose, raffinose, arbutin (delayed), salicin (delayed), ethanol (delayed), glycerol (delayed), ribitol (delayed), D-glucitol, D-mannitol, myo-inositol, D-glucuronate, D-gluconate, 2-keto-D-gluconate, 5-keto-D-gluconate, D-glucarate, quinic acid, succinate, citrate (delayed) and DL-lactate (delayed). No growth occurs on inulin, methyl $\alpha$-D-glucoside, soluble starch, lactose, D-ribose, Larabinose, D-arabinose, L-rhamnose, erythritol, xylitol, Larabitol or galactitol. Utilization of nitrogen compounds: positive for nitrate, nitrite, ethylamine (delayed), Dglucosamine, L-lysine (delayed) and cadaverine (delayed), negative for creatine and creatinine. Growth in vitaminfree medium is absent. Reactions to Diazonium blue B and urease are positive. Starch-like compounds are not produced. Growth occurs at $25{ }^{\circ} \mathrm{C}$ but not at $30{ }^{\circ} \mathrm{C}$.

The type strain Pa- $78^{\mathrm{T}}\left(=\mathrm{VKM} \mathrm{Y}-2971^{\mathrm{T}}=\mathrm{CBS} 11420^{\mathrm{T}}\right)$ was isolated from dead needles of Picea abies (L.) Karst. in Moscow region (Russia).

\section{Latin diagnosis of Rhodotorula straminea Golubev et Scorzetti sp. nov.}

In aqua D-glucosum et peptonum et extractum fermenti continente, post dies 3 cellulae elongate, fusiformes, curvatae, guttatae, $(2.5-4.3 \times 8.5-18.7 \mu \mathrm{m})$, singulae vel binae, gemmatione polari reproducentes. Post unum mensem, pellicula crassa et sedimentum formantur. In agaro morphologico (Difco) post unum mensem cultura in striis griseocremea, glabra, nitida, butyrosa, margo integra. Ballistoconidia nulla. In agaro farina Zea maydis confecto post dies 10 pseudohyphae primitivae formantur. Status sexualis non apparet. Non fermentat. D-Glucosum, D-glucosaminum (exigue), $\mathrm{N}$-acetylglucosaminum, D-galactosum (exigue), L-sorbosum (exigue), D-xylosum (exigue), sucrosum, maltosum (lente), trehalosum, melezitosum, raffinosum, amylum (exigue), ethanolum, glycerolum (lente), ribitolum, D-glucitolum, Dmannitolum, myo-inositolum, D-glucuronatum, D-gluconatum, 5-keto-D-gluconatum, D-glucaratum, acidum quinicum, succinatum, citratum (lente) et DL-lactatum (lente) assimilantur neque inulinum, methyl $\alpha$-D-glucosidum, melibiosum, lactosum, cellobiosum, arbutinum, salicinum, D-ribosum, Larabinosum, D-arabinosum, L-rhamnosum, erythritolum, xylitolum, L-arabitolum et galactitolum. Kalium nitricum, kalium nitrosum, ethylaminum (lente), D-glucosaminum, Llysinum (lente), cadaverinum (lente) et L-tryptophanum assimilantur, creatinum et creatininum non assimilantur. Vitamina externa at crescentiam necesseria sunt. Reactiones Diazonium blue B et ureasii positivae. Materia amyloidea iodophila non formatur. Crescit in $25{ }^{\circ} \mathrm{C}$, non crescit in $30{ }^{\circ} \mathrm{C}$. Typus Ps $-130^{\mathrm{T}}$ isolates ex foliis acicularibus Pinus sylvestris L. delapsis (Rossia), conservatur in collectione micro-organismorum (=VKM Y-2964 ${ }^{\mathrm{T}}$ ) Acad. Sci. Rossicum (Pushczino, Rossia) et in collectione zymotica (=CBS $10976^{\mathrm{T}}$ ) Centraalbureau voor Schimmelcultures (Utrecht, Hollandia). 


\section{Description of Rhodotorula straminea Golubev et Scorzetti sp. nov.}

Rhodotorula straminea (stra.mi'ne.a. L. fem. adj. straminea of or pertaining to straw, referring to the origin of the isolates from litter).

After 3 days in D-glucose/yeast extract/peptone broth, cells are elongate, fusiform, often curved, width/length ratio 2.5-5.5 (mean 4.2), 2.5-4.3 ×8.5-18.7 $\mu \mathrm{m}$ (mean $3.2 \times$ $13.4 \mu \mathrm{m}$ ), reproducing by polar budding, single or in pairs, and contain oil droplets. After 1 month, a thick pellicle and a sediment are formed. Streak culture on yeast morphology agar (Difco) is greyish-cream, smooth, glistening and butyrous with an entire margin. No ballistoconidia are observed. After 10 days in slide cultures on corn meal agar a primitive pseudomycelium is produced. No sexual state is observed. Fermentation is absent. The following carbon compounds are assimilated: D-glucose, D-glucosamine (weak), $\mathrm{N}$-acetylglucosamine, D-galactose (weak), L-sorbose (weak), D-xylose (weak), sucrose, maltose (delayed), trehalose, melezitose, raffinose, soluble starch (weak), ethanol, glycerol (delayed), ribitol, D-glucitol, D-mannitol, myoinositol, D-glucuronate, D-gluconate, 5-keto-D-gluconate, D-glucarate, quinic acid, succinate, citrate (delayed) and DLlactate (delayed). No growth occurs on inulin, methyl $\alpha$-Dglucoside, melibiose, lactose, cellobiose, arbutin, salicin, D-ribose, L-arabinose, D-arabinose, L-rhamnose, erythritol, xylitol, L-arabitol or galactitol. Utilization of nitrogen compounds: positive for nitrate, nitrite, ethylamine (delayed), D-glucosamine, L-lysine (delayed), cadaverine (delayed) and L-tryptophan, negative for creatine and creatinine. Growth in vitamin-free medium is absent. Reactions to Diazonium blue B and urease are positive. Starch-like compounds are not produced. Growth occurs at $25{ }^{\circ} \mathrm{C}$ but not at $30{ }^{\circ} \mathrm{C}$.

The type strain Ps $-130^{\mathrm{T}}\left(=\mathrm{VKM}\right.$ Y $-2964^{\mathrm{T}}=\mathrm{CBS} 10976^{\mathrm{T}}$ ) was isolated from dead needles of Pinus sylvestris L. in Moscow region (Russia).

\section{Acknowledgements}

Research at RSMAS (University of Miami) was partially supported by the National Science Foundation (USA) Grant DEB 0206521 and at VKM by the Program 'Molecular and Cell Biology' (Russian Academy of Sciences). The authors are indebted to Professor J. W. Fell for critical reading of the manuscript, to Dr N. W. Golubev and to Ms M. A. Tomashevskaya for technical assistance.

\section{References}

Aime, M. C., Matheny, P. B., Henk, D. A., Frieders, E. M., Nilsson, R. H., Piepenbring, M., McLaughlin, D. J., Szabo, L. J., Begerow, D. \& other authors (2006). An overview of the higher level classification of Pucciniomycotina based on combined analyses of nuclear large and small subunit rDNA sequences. Mycologia 98, 896-905.

Barnett, J. A., Payne, R. W. \& Yarrow, D. (2000). Yeasts: Characteristics and Identification, 3rd edn. Cambridge: Cambridge University Press.

Fell, J. W. \& Statzell-Tallman, A. (1998). Rhodotorula Harrison. In The Yeasts: a Taxonomic Study, 4th edn, pp. 800-827. Edited by C. P. Kurtzman \& J. W. Fell. Amsterdam: Elsevier.

Fell, J. W., Boekhout, T., Fonseca, A., Scorzetti, G. \& StatzellTallman, A. (2000). Biodiversity and systematics of basidiomycetous yeasts as determined by large subunit rDNA D1/D2 domain sequence analysis. Int J Syst Evol Microbiol 50, 1351-1371.

Golubev, W. I. (1989). i-Inositol catabolism and taxonomic significance of yeast ability to assimilate D-glucuronate. Mikrobiologiya 58, 276-283 (in Russian).

Golubev, W. I. (2006). Antagonistic interactions among yeasts. In Biodiversity and Ecophysiology of Yeasts, pp. 197-219. Edited by C. A. Rosa \& G. Péter. Berlin: Springer.

Golubev, W. I., Sampaio, J. P., Alves, L. \& Golubeva, E. W. (2006). Cryptococcus silvicola nov. sp. from nature reserves of Russia and Portugal. Antonie van Leeuwenhoek 89, 45-51.

Kurtzman, C. P. \& Fell, J. W. (1998). The Yeasts: a Taxonomic Study, 4th edn. Amsterdam: Elsevier.

Margesin, R., Fonteyne, P. A., Schinner, F. \& Sampaio, J. P. (2007). Rhodotorula psychrophila sp. nov., Rhodotorula psychrophenolica sp. nov. and Rhodotorula glacialis sp. nov., novel psychrophilic basidiomycetous yeast species isolated from alpine environments. Int J Syst Evol Microbiol 57, 2179-2184.

Scorzetti, G., Fell, J. W., Fonseca, A. \& Statzell-Tallman, A. (2002). Systematics of basidiomycetous yeasts: a comparison of large subunit D1/D2 and internal transcribed spacer rDNA regions. FEMS Yeast Res 2, 495-517.

Shivaji, S., Bhadra, B., Rao, R. S. \& Pradhan, S. (2008). Rhodotorula himalayensis sp. nov., a novel psychrophilic yeast isolated from Roopkund Lake of the Himalayan mountain ranges, India. Extremophiles 12, 375-381.

Yarrow, D. (1998). Methods for the isolation, maintenance and identification of yeasts. In The Yeasts, a Taxonomic Study, 4th edn, pp. 77-100. Edited by C. P. Kurtzman \& J. W. Fell. Amsterdam: Elsevier. 